\title{
Local R\&D Capacity Building Strategies in the Two Decades Prior to the Great Recession of 2008: The Case of ICTs in Spain
}

\author{
Ángel Calvo
}

\begin{abstract}
This article analyses the standardisation of business $R \& D$ in a technologically dependent country -Spain-, in a high technology sector -telecommunications and electronics -and in a key stage of its journey, marked by a double process of rapid technological change and intense liberalisation. Focused on the key telecommunications company - CTNE/Telefónica but attentive to the general framework, its purpose is to explore from a business perspective whether the semi-public telecommunications monopoly company -Telefónicastrengthened the predominant $R \& D$ model in Spain or contributed to correct it, in a context of modernization and growth of the Spanish economy and with an eye on the foreign market. It seeks to explore, in this way, the effects of strategies to boost local R\&D capabilities in telecommunications and in some of the explanatory causes of the difficulties encountered. The article, with a clear interdisciplinary approach and descriptive orientation, is based primarily on exceptional primary sources, which allow both to verify results and reveal the gestation of policies.

Index Term-ICT, Local R\&D, Multinationals, Telefónica.
\end{abstract}

\section{INTRODUCTION}

The long-term importance of technological change and learning became central to economic analysis during the 1980 s, as for instance in new theories of trade and growth. It underpin analyses of the convergence or divergence of economies and emerged as one of the key factors behind the differences in growth among developed countries ${ }^{1}$.

Two main approaches are opposed in the study of technological development: the systemic approach of national innovation systems and the linear model of innovation. The first approach reflects the increasing attention paid to the economic role of knowledge flows and the relationships between industry, government and universities in the development of science and technology. Innovation and technical advancement arise of a complex set of relationships among actors producing, distributing and applying various kinds of knowledge. The innovative performance of a country depends to a large extent on how these actors - private enterprises, universities and public research institutes and the people within them- relate to each other as elements of a collective system of knowledge creation and use as well as the technologies they use. In contrast, the linear model conceives knowledge flows as a sequence from the initiator of innovation - science - to an increase in scientific inputs and in the number of new innovations and technologies flowing downstream [1]. ${ }^{2}$ From

Published on March 28, 2020.

1 The representatives are Krugman; Lucas, Grossman, and Helpman and Romer; Abramovitz; Baumol and De Long, as well as Fagerberg and Cantwell. this this point on, the debate has been enhanced by the role developed by the regions and the developing countries [2][3]-[4]. In part, the controversies underline the importance of the innovation capacities of networked rather than national "smart" regions in local development strategies; building R\&D capacity, by itself, will not solve many of the most pressing development challenges facing the developing countries.

This study relies rather on the first of the aforementioned approaches. It aims at providing new evidence for the definition of Spain as a country with low international competitiveness, dependent on technology in general and in the leading industries of telecommunications in particular. In order to achieve this cardinal objective, it adopts an interdisciplinary perspective, mainly from the business history and a descriptive orientation, to explore the strategies for boosting local R\&D capacities in Spain and the explanatory causes of the difficulties encountered. In its substantially qualitative nature, the case relies on hitherto unexplored primary sources of business origin (primarily IT and R\&D), on statistics and official reports and on oral testimonies, all of which are reinforced by a broad and select secondary literature. In this sense, the case provides elements of understanding about the behaviour of countries outside the central economies. References [5]-[6] place Spain among the intermediate economies.

Spain was identified by its scarce information on business action in R\&D in advanced industry and its frequent absence in international debates on R\&D policies [7]. This nationstate, listed in the statistics, is sometimes left out of the analysis.

The study ties in with the efforts made years ago by applied economics, concerned about the absence of studies and attracted by the most heated debates on technological change, focused at the start of the 21st century on the scope of internationalization and its relationship with competition in developed countries [8]-[9]. Production and research in advanced technologies had become increasingly global to the extent that we were talking about "global innovation systems" $^{\text {"3 }}$, a new scenario in which the various players had to move. Among them, multinational companies stand out, agents of the export not only of capital but also of advanced knowledge and accumulated experience to the receiving economies [10]-[12]-[13]-[14]-[15]-[16].

Ultimately, the study engages in dialogue with the institutionalist approach, which addresses the pattern of R\&D spending through historical cases in the long term and

${ }^{2}$ The postulates of the school of national innovation systems were promoted almost simultaneously by Lundvall, Freeman and Nelson.

3 A good overview of the debate on the effects of globalization, with opposing stances: Lazonick [11]. 
proposes an analytical framework of technological capabilities for industry in developing countries ${ }^{4}$. It is also supported by works on economic history, some of which focus on the stage immediately prior to the one chosen here, while others are committed to pointing out the permanent and scarce importance of investment, considered an input by the literature [5], in R\&D in Spanish economic growth [17] - [18] [19] - [20].

The work follows a three-section structure, which successively analyses the role of companies in the generation of R\&D in Spain from an aggregated approach, the creation of a central R\&D unit -Telefónica Investigación y Desarrollo (TIyD)- and the strategy of technological creation and accumulation.

Once the structure is defined, several initial points of a general nature are appropriate. Starting with the definition of the size of the protagonist, it is important to emphasise the extraordinary importance of Telefónica, a key company in the Spanish telecommunications sector, which can be seen in its weight in the Spanish economy, estimated at between 1.4 and $1.8 \%$ of GDP in the 1980 s and $1.79 \%$ in the year 1990 [21]. The time frame chosen is justified by the intensity and speed of technological change - microelectronics, fibre optics and information technology - and by the wave of liberalisation that followed the break-up of the North American giant AT\&T into regional operators and finally affected Spain. In the conceptual clarifications, according to the OECD, we define $R \& D$ as a key form of investment in knowledge differentiated from spending on education and ICT-, which includes a systematic effort, aimed at expanding the stock of knowledge, and the use of it to devise new applications.

Scientific research and technological development (internal $\mathrm{R} \& \mathrm{D}$ ) is part of technological innovation, which also includes the acquisition of $R \& D$ (external R\&D), machinery, equipment and software, as well as other external knowledge (patents, licences, etc.). Training, introduction of innovations to the market (marketing) and design or other preparations for production and/or distribution complete the list [22]. On the other hand, it is compared to a knowledge-intensive industry, according to the double industrial criteria and, in accordance with the problems dealt with, to a business one. This includes the telecommunication equipment supply industry, which is highly and increasingly intensive in $R \& D$ due to the progressive software content and the shortening of the life cycle. ${ }^{5}$

A range of considerations also apply to the issue under analysis. The ability to create, disseminate and exploit knowledge and information is increasingly crucial for the competitiveness of the economy and development. A distinctive feature of Spanish economic development has been the chronic deficit of advanced technology, especially strategic innovation, with the corollary of an acute dependence on imports of tangible goods and know-how. The amounts paid for technology imports in the form of royalties and technological assistance were equivalent to $0.67 \%$ of GDP, $4.4 \%$ above the average of the European leaders [23]. ${ }^{6}$ In the technological balance of Spain, and of some regions, we could add, the coverage with own technology never exceeded values of $35 \%$ and the deficit was accentuated even in the 1980s, a diagnosis of the reality not very flattering with the policies undertaken in the different responsible entities. ${ }^{7}$ The timid involvement of the UCD - promoter of the Electrotechnical Research and Development Programme (PIE) in the electricity sector in response to requests from industry - and the pro-industrial policy of the PSOE, articulated with powerful instruments such as the National Electronic and Information Technology Plan (PEIN) and the Science Act, did not have the expected effects [24]. ${ }^{8}$ The new strategic role given to R\&D by the National Institute of Industry (I.N.I.) was not enough either, nor was the fact that the entity's electronics division expenditure for this concept was multiplied by 6.5 in 1979-1984. Defects in management and policy design hampered the actions of independent bodies designed to promote the technological development of Spanish industry, the most significant example of which was the Centre for the Development of Industrial Technology (Centro para el Desarrollo Tecnológico Industrial, CDTI). Two points, disturbing as they are, have just defined the outlined picture. The first, to which we shall return, is the fatal $1 \%$ barrier to GDP against which R\&D expenditure was crashing, well below the $2.33 \%$ of the leading European group [27]. The second concerns the composition of expenditure, which is dominated by current expenditure and at the expense of capital expenditure.

Finally, a reference to geographical aspects seems pertinent. R\&D activities in Spain were unevenly distributed throughout the territory: more than half of the companies were located in Catalonia and Madrid, a proportion far removed from the $15 \%$ of the Basque and Valencian Autonomous Communities [25]. In a less static approach, it is significant the collapse of Madrid, the maintenance of Catalonia, the rise of Valencia and the Basque Autonomous Community and the emergence of others, including Aragon. In sight of the current relevance of the persistent technological dependence, it is necessary to ask on which factors it is based. We take into account Spain's status as an intermediate or peripheral country, included alongside a varied group of nearby nations among the 'moderate innovators' by the European Innovation Scoreboard. However, we ruled out size as a determining factor from the outset because of the lessons provided by cases such as Finland.

\section{THE COMPANIES IN THE CREATION OF R\&D IN SPAIN: AGGREGATE APPROACH}

from Spanish companies; this situation worsened between 1985 (19\% of the total) and 1993: Desarrollo Tecnológico, November 1994, p. IV.

${ }^{8}$ The PEIN was promoted by Joan Majo from the direction of Electronics and Information Technology and immediately linked up with the CTNE, of which he was a director: Interview with Joan Majó, Barcelona, 17/9/2015. Around 1995, the main beneficiaries of the aid granted by the PEIN (1,991.9 million pesetas) were consumer electronics $(26.22 \%)$, microelectronics and electronic components $(22.25 \%)$, telecommunications $(19.44 \%)$ and industrial electronics (13.99\%): Ministerio de Industria y Energía (1983); about the PIE, orchestrated by this Ministry in 1980 [24]. 
The institutionalization of scientific technology dates back to the use of scientists in industry as researchers, a stage preceded in Germany at the beginning of the 19th century by the conversion of medieval universities into higher research institutions. Modern innovation systems include higher research institutions, industrial centres and governmentfunded agencies. The analysis of the role of companies in the creation of $R \& D$ in Spain requires the definition of the national science-technology-industry system and the economic resources allocated to it as a preliminary step. The task is not easy due to the complexity of the factors involved and the lack of homogeneous serial data for the period [26]. ${ }^{9}$

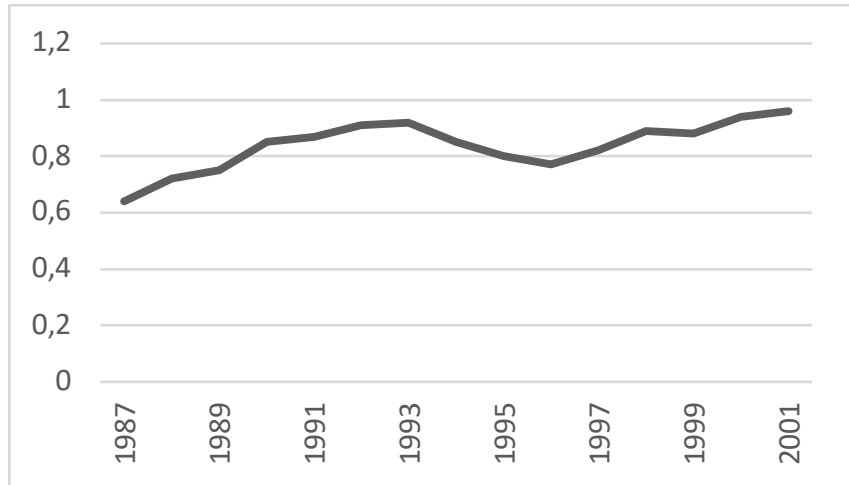

Fig 1. R+D expenditure/GDP (\%) in Spain

In a first chronological cut (1987-1996), general R\&D expenditure in Spain grew in the first four years, collapsed in 1992 and then recovered above the previous level. In relative terms as a percentage of GDP, general R\&D expenditure ranged from the lowest of $0.64 \%$ in 1987 to the highest of $0.92 \%$ in 1993. In a second chronological cut (1997-2002), the period before and immediately after the technology bubble, a growth trend from $0.82 \%$ to $1.03 \%$ of GDP was observed (Fig. 1) and a similar curve drew the per capita R\&D expenditure.

Obviously, we are interested in focusing on R\&D in the ICT sector, whose main indicators we know. To start with the most elementary, towards the end of the period under study the number of companies with internal R\&D was 1,415 . Secondly, the sector tended to shift to the tertiary sector its activity due to the decrease of industrial companies -a little more than a quarter- in favour of service companies, clearly predominant in the total expenditure on R\&D. This trend of R\&D towards the service sector was completed with a discrepant behaviour in terms of $R \& D$ expenditure per company, as manufacturing companies tended to increase and service companies to decrease (Comisión Interministerial de Ciencia y Tecnología, 2008, p. 39).

In drawing up the overall picture, it is worth considering the weight of the companies. To quantify, in 1990, business expenditure on R\&D represented $0.49 \%$ of GDP in Spain. After four years, this ratio was half that of the EU and $39.7 \%$ of the OECD (Comisión Interministerial de Ciencia y Tecnología, 1998, p. 11). The situation had hardly improved in the years that followed, since at the beginning of the new

\footnotetext{
${ }^{9}$ In the case of the USA, studies on the impact of the environment in which innovation takes place, define it by the system of government and the policies applied at different levels -federal, state and local: [26].

${ }^{10}$ Spain: 49\%; France: $54 \%$ : [27]. The effectiveness of the R\&D system is usually assessed by the weight of the companies in it, since they are the ones
}

millennium, business expenditure on $\mathrm{R} \& \mathrm{D}$ was equivalent to $0.52 \%$ of Spanish GDP. Comparatively, the low percentage of business expenditure on R\&D as a proportion of GDP resulted in a lower share than in other European countries, despite the fact that they were the main contributors. This added another worrying factor for Spain, given that business expenditure on $R \& D$ is attributed a greater impact on productivity than the public- [27] [28]. ${ }^{10}$ In terms of innovation, the number of innovative companies reached onefifth of the total in 2000-2003 and slightly more in the following three-year period (Comisión Interministerial de Ciencia y Tecnología, 2008, pp. 32-33. ${ }^{11}$

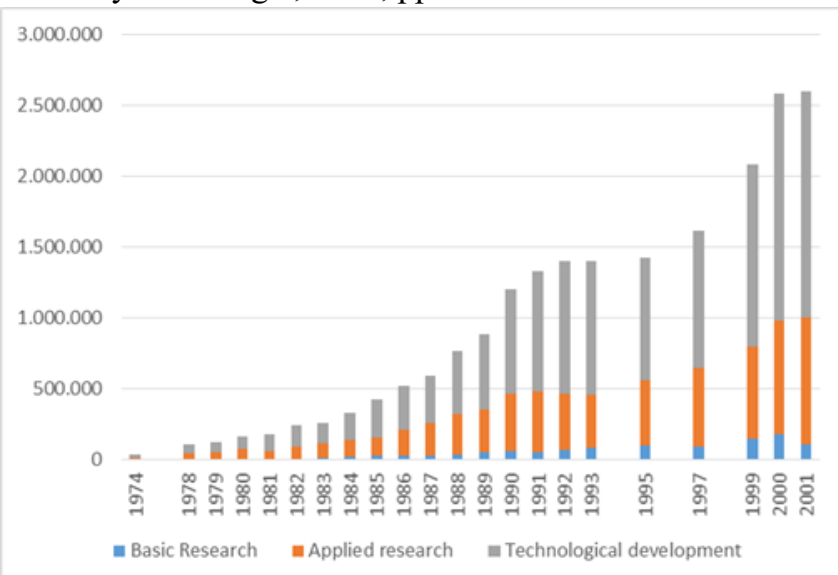

Fig. 2. Internal expenditure of companies on R\&D by year and type of research. Spain (thousands of euros)

According to Instituto Nacional de Estadística (National Institute of Statistics, I.N.E.), two features of business internal R\&D spending were: the growth since the beginning of the democratic transition until 2001, albeit not uninterrupted, and the overwhelming predominance of current over capital expenditure. Considering total domestic expenditure on R\&D in relation to GDP, companies outperformed the other actors - government and higher education - in percentage terms. Even so, the structure of expenditure according to the sectors of execution denotes another of the system's main weaknesses: the participation of the business sector was far from optimal levels to ensure its technological capacity and thus a better balance in the technological balance. By comparison, at the same time Spain had a poor profile in terms of companies with internal R\&D $-11 \%$ compared to levels between $25-32 \%$ in the leading countries and $16-24 \%$ in the followers [29].

Another significant indicator of the national R\&D effort of companies, also regarded as an input [5] - staff employed, measured by the Full Dedication Equivalent (Equivalencia a Dedicación Plena (EDP) - shows growth from the second half of the 1980s onwards. This rampant trend stopped afterwards and did not pick up again until the following decade [30]. The change in trend was accompanied by a change in the composition of the staff, determined by the more intense increase in researchers to the detriment of assistants and over technicians. Two significant connotations of this remarkable increase in staff qualifications should be noted. This

that convert knowledge assets into innovations and economic growth: and economic growth [28].

${ }^{11}$ Interestingly, in comparative terms and in one specific year (2004), the percentages of innovative companies in Spain match average levels in the European Union and higher than those of countries such as the Netherlands and France. 
movement was led during the entire period by the companies, which displaced the Administration in the number of researchers, in the same way that the aforementioned total internal expenditure on R\&D with regard to GDP. As we limit ourselves to the period 1988-1989, the improvement of the workers' capacities was carried out fundamentally by incorporating engineers and/or young graduates and, to a lesser extent, by hiring personnel with previous specific experience in R\&D. As for the second connotation -size-, the improvement of capacities was more accentuated in large companies than in small ones and increased, in turn, the probability of obtaining innovations.

It remains to close the stimulating factors of innovation with the degree of external financing and its relation to the investment intensity of companies in R\&D. Companies that financed innovation with subsidised loans predominated (4.8 and $2.5 \%$ ), higher figures than those that spent on R\&D with or without funding $(2.5$ and $1.7 \%)$ and those that sought external funding unsuccessfully (3.9 and $1.8 \%$ ). There was a positive relationship between the investment effort of the companies and the degree of financing obtained.

In the closing years of the 20th century, the R\&D effort (R\&D expenditure/sales) of companies in Spain remained stagnant and was dominated by companies with more than 200 workers (1.23\% compared to $0.4 \%$ for small companies) (SEPI (2001), pp. 22-23). The early years of the millennium show a downward trend in the percentages of all enterprises $\left(0.93 \%\right.$ in 2000 and $0.83 \%$ in 2005) [30]. ${ }^{12}$ Depending on the source of financing and the size of the companies, smaller companies had greater recourse to public financing than larger ones (3.9\% and 3.1\% respectively) in 2000. Moreover, the new configuration of the territory fully brought the autonomous regions into the R\&D system.

Such enterprises were mainly identified by their predominantly small size - more than half with less than 50 employees - and the varied sectoral distribution, although with a greater weight of the machinery, mechanical and electrical equipment, chemical, food and service industries. With regard to ownership, in the overwhelming majority of cases $(97 \%)$ R\&D funding from the State was concentrated in indigenous companies $(85 \%) .{ }^{13}$ For a number of periods, we know the profile of state-funded companies according to their age; in the five-year term 1978-1982, the most recent ones, those created after 1971, clearly predominated. ${ }^{14}$ During these years, R\&D was preferably market-oriented, a clearly visible trend in the percentages of around $80 \%$ of the product innovation projects approved by the CDTI.

\footnotetext{
${ }^{12}$ There are surprising contradictions, such as the information that in 2000 the investment effort of small companies was higher than that of large ones. ${ }^{13}$ See [25]. On average, the companies benefiting from the FEDER-CDTI global subsidy spent $0.8 \%$ of their turnover on R\&D in 1995 (2,300 million pesetas) and had 112 employees, i.e. their size and R\&D effort was two to three times less than that of the average CDTI company at national level: Noticias CDTI, March 1996, p. 2.

${ }^{14}$ Companies incorporated after 1980: $9 \%$; between 1971-80: $40 \%$; 1961 70: $18 \%$; between 1951-60: $10 \%$; between 1941-50: $11 \%$; before 1941: 12 $\%$ (CDTI, Memoria, 1982, p. 33).

${ }^{15}$ In $1993,88.2 \%$ of the participants in Special Share projects were mainly Spanish, while the 39 multinationals represented the remaining $11.8 \%$ of the total: [10]
}

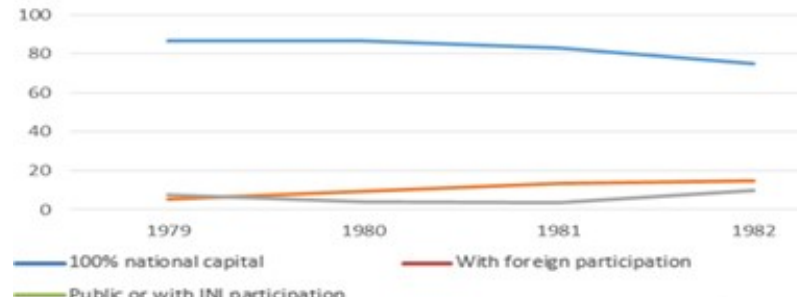

Fig. 3. Nature of the companies proposing R\&D projects (\%). Spain

Aspects relating to the prevailing trend towards globalization deserve specific attention. Fig. 3 shows this smooth progression of project finance for joint ventures with foreign capital in the years of industrial policy change with the coming of the socialists to power. Until 1998, the number of innovation projects by foreign companies amounted to $12 \%$ $[31] .{ }^{15}$ On the other side of the moon, the increase in FDI in Spain at the end of the 1980s was compounded by a drastic fall in $R \& D$, due to the collapse of two sectors, namely consumer electronics and communications [32]-[33]-[34]. ${ }^{16}$

\section{FORMALISING THE INNOVATION FUNCTION: INTERNAL R\&D}

Undoubtedly the aggregate approach taken by conventional business R\&D studies has a high explanatory value. On this basis, knowing which companies were involved and their policies, as well as their location and size, among other connotations, can provide new evidence for general knowledge.

In the absence of complete official records, partial data, properly processed, shed light on this varied reality of business research centres in Spain. ${ }^{17}$ A thorough and patient search has allowed us to bring to light twenty-five R\&D centres in the electronics and telecommunications industry in 1990, undoubtedly a small percentage of the existing total. An overwhelming majority were concentrated in the Madrid and Barcelona areas (eleven and eight, respectively). The remaining six were scattered in Biscay, Valencia, Almeria, Navarra, Santander and, presumably, Malaga. Companies with a strong research capacity, which had by then succumbed to the crisis, have not been able to join the, we insist, incomplete list of 1990. To this category belongs the unique Telesincro, which has been the sole protagonist of a successful experience in the design and production of computer hardware in Spain [35], together with the Catalan manufacturer of consumer electronics Compañía Electrónica de Comunicaciones, the result of the merger in 1970 between Emerson Electrónica Española and Kolster Ibérica.

In the telecommunications equipment supply industry in Spain, small business centres predominated and, strictly speaking, only five (Standard Eléctrica, later converted into Alcatel-SESA, CESELSA, Compañía Internacional de Telecomunicación Electrónica S.A. -CITESA-, Industrias de

\footnotetext{
${ }^{16}$ In Spain, the share of foreign affiliates in industrial R\&D fell between 1985 and 1996, due to the greater growth in $R \& D$ expenditure by national companies, a fact that also occurred in Canada and Australia [33]. Emphasis on the lower investment of some multinationals in R\&D with respect to national manufacturers: Información comercial española, 577-579, 1981, p. 101. The preferences of multinationals for their investments in R\&D through their subsidiaries migrated from the Mediterranean area in the early 1990s to the countries of Eastern Europe and to the central economies in the following re [34].

${ }^{17}$ In 1987 , barely 200 companies were doing research on a regular basis; four years later, there were more than a thousand: "Interview with Humberto Arnés, director of the CDTI," Expansión, 1/7/1991.
} 
Telecomunicación, a subsidiary of Ericsson -INTELSA- and, especially, TIyD) escaped from the tiny [36]. ${ }^{18}$

Standard Eléctrica (SESA) stood out for its tradition and size, a company that should be noted for its close links with Telefónica as an investee supplier, which dedicated $1.5 \%$ of its sales to financing research projects in Spain, half of its contribution to the IT\&T research pool and slightly above the national average, known for later years. The organisational instrument was its Research Centre (CISE), which was fully integrated with the other eight world centres of the older multinational IT\&T and with those of the Spanish National Telephone Company (CTNE) within the country. Unlike the own engineering departments, it focused its work on the medium and long term. Its staff multiplied by twenty between the beginning and 1980, more than half of them being qualified personnel. Of great interest for the relevance given here to the organizational aspect, an independent venture of the R\&D department of SESA without abandoning its roots technology and training- gave rise to a new company, called Formación y Consultoría, S.A. (Fycsa) ${ }^{19}$

In CITESA its investment effort in R\&D of 3.5\% over sales stands out, as well as the substantial orientation to product innovation and the strategy of alliances with its counterparts - SESA and IT\&T - to access the R\&D programs and resources of the remaining companies of the North American multinational, the largest world supplier in the field of telecommunications and electronics ${ }^{20}$.

INTELSA devoted the bulk of its technical and research activities to adapting Ericsson's AXE switching equipment to Spanish networks, without excluding the world market ${ }^{21}$. This was also the aim of its alliance policy, as shown in the 1984 agreement with the CTNE and the research centre of Ericsson Spain in order to boost the resources devoted to technical activities on a selective basis $[38]^{22}$. The priorities also extended to the development of products demanded by CTNE, own products for all types of markets and Ericsson products designated by the Swedish company. From 1986 onwards, INTELSA was able to count on a hardware and software research centre, which, in addition to serving its own clientele, was oriented towards the prospecting and determination of systems for Spain and abroad, as well as the more specific demand from Telefónica and Ericsson, the company's founding partners. As the economic framework widened with the process of insertion into the European

\footnotetext{
${ }^{18}$ Acs; Audretsch (1990) [36] attribute to the small companies a performance in innovations/employee 2.4 times higher than the big ones; some scholars explain the R\&D in these units by the search of competitiveness.

${ }^{19}$ ElP, $14 / 1 / 2001$; between 1986 and 1991, R\&D staff increased by a factor of 1.37 and funding more than tripled: SESA, Annual Report(s); in 1986 R\&D investment was $10.6 \%$ of sales: SESA, Annual Report 1986, p. 31 The CISE, created around 1957, was a leader in traffic and network planning Manuel Márquez (President of SESA), Audio of the session of the Committee on Transport and Communications (hereinafter Audio), Congress of Deputies, Congress of Deputies, 2/2/1982; Comunicaciones Eléctricas $55,4,1980$, p. 353.

${ }^{20}$ CITESA, Memoria anual, 1976, p. 4; ABC, 24/8/1965. Product innovation opened the world market to CITESA: Intervention of the President of CITESA, Audio, Congress of Deputies, 2/2/1982. In the public sector, EISA employed 49 people in R\&D, most of them graduates, and spent amount equivalent to $6 \%$ of sales, coming from external organizations (mainly CAYCIT and CDTI): EISA, Memoria 1983 (INI Historical Archive); EISA Programa operativo año 1985.

21 INTELSA, Memoria, 1979; in 1985, INTELSA delivered an ISDN prototype to Telefónica, thus reinforcing the digitalization of existing networks [37]. The future of Telefónica's R\&D, which was heavily influenced by mobile telephony, lay precisely in network technology, to which almost all of its patents belonged years later: El Confidencial, $17 / 6 / 2013$.
}

single market, INTELSA collaborated in R\&D projects for EEC programmes [39]. ${ }^{23}$

As a simple note, we point out the laboratory of Telettra Española, a research centre completely independent of the one that had the parent company in Italy, widely diversified in its lines of research and subsequently integrated into Alcatel $^{24}$.

In the case of CESELSA, of interest for its trajectory as a smaller but very dynamic company and as an embryo of INDRA, it was the competition with the public sector for supply contracts for the administration in unfavorable conditions that pushed it along the path of R\&D aimed at achieving national technological developments [40] and [41]. That attachment in successive competitions for the own technology - let's call it the technological independence allowed him to extend the range of products. The formula for developing in-house technology proved to be successful, judging by the company's growth, which was strengthened by subcontracting to other national companies ${ }^{25}$. One feature common to subsidiaries of multinationals based in Spain will not be stressed enough: the accumulation of know-how from the parent company's extensive network of R\&D centres. Let us now see how the case study supports, modifies, qualifies or corrects what has been explained.

\section{FROM THE ORGANIC UNIT IN THE CTNE (CIE) TO THE SUBSIDIARY OF R\&D: TELEFÓNICA INVESTIGACIÓN Y DESARROLLO, S.A.}

The deepening of the formalization of R\&D came from the monopoly operator by separating these activities from the parent company and creating Telefónica Investigación y Desarrollo, S.A. in 1987, the crowning stage of a long journey that began two decades earlier with the Research and Studies Centre (CIE) and was further intensified with the creation of the R\&D Centre (CID), which replaced the CIE, and the Technology, Planning and Industrial Department $(1983)^{26}$.

The extraordinary speed and depth of technological change required significant research activity to support product innovation ${ }^{27}$. Some of the initiatives coexisted partly with the State's plans and partly with those of the company itself to bring Spain out of its backwardness and to promote microelectronics in its most advanced form. The various plans culminated in the creation of AT\&T Microelectrónica

${ }^{22} \mathrm{R} \& \mathrm{D}$ involved a high level of resource commitment, reaching $12 \%$ of all staff. Together with the R\&D center, Ericsson had in Spain, its second market, groups that developed new applications and products; the subsidiary had the advantage of being connected to the network of fifteen R\&D centers of the headquarters.

${ }^{23}$ INTELSA, Memoria, 1984, p. 7. The 60 or so graduate engineers of INTELSA's technology centre doubled in 1988; as a link with the public sector, it trained engineers for the Madrid Institute of Technology: Ericsson Contact, 1986, 4, p. 6

${ }^{24}$ There are coincidences with some lines followed by the NECC. The company claimed as proof of independence that in the radio system the UHF was investigated in Spain and the high capacity systems in Italy; the same was true of the terminals (Spain) and the charging systems (Italy). The microwave network in Uruguay was deployed with technology taken from the Italian matrix: Mariano Jaquotot (president of Telettra Española), Audio, Congress of Deputies, 2/2/1982.

${ }^{25}$ The 30 engineers and some 70 employees in 1979 were multiplied a decade later by 13.3 and 10 respectively.

${ }^{26}$ CTNE, Memoria (hereinafter, CTNEM) 1983

${ }^{27}$ A particularly relevant line of action was the design of integrated circuits, which became an organisational reality: the Integrated Circuit Centre: Audio, Congress of Deputies, 2/2/1982. 
de España, a joint venture with the North American multinational that provided the brand [42]. ${ }^{28}$ This commitment also fitted in with the policy of an industrial holding company advocated by Luis Solana, whereby Telefónica used its purchasing power to sponsor cutting-edge technology, albeit in a subordinate manner to a technology leader, thus making up for the lack of private investment. Part of this replacement effort was aimed at negotiating R\&D activities in Spain, involved in the overall R\&D strategy of the technology partner. ${ }^{29}$

Already in the midst of the change in the political cycle and the industrial crisis, market orientation was specified in the four-year Technology Plan (1983-1986), the annual Development and Approval programmes and the definition of the conceptual framework for standardisation and approval agreed with the Administration. ${ }^{30}$ The technological plan envisaged a specialised R\&D centre, standardisation and approval activities and an innovation programme for equipment and systems ${ }^{31}$. The centre was looking for a national offer of products based on its own technology, the development of goods with an exploratory character and a collaborative scheme with other centres in the creation and/or assimilation of competitive technologies. Finally, the recourse to external advice led to prioritizing the development of cutting-edge technology in telecommunications. This reformulation of the idea of the centre had to be materialized in commercially exploitable patents and in a search for excellence at a world level. ${ }^{32}$

Once the constitution of the CTNE's industrial holding company was completed in 1985, the next step was its rationalisation as a means of promoting activities, boosting resources and making the investments made profitable. ${ }^{33}$ But Spain's integration into the EEC as a full member forced it to dispense with the industrial holding company. At that very moment, Telefónica Investigación y Desarrollo (TIyD) found its place within the new group scheme: the mission of concentrating R\&D activities and reaching sufficient critical mass. In practice, it went beyond the concept of an organic unit of the CIE, with an independent and centralizing unit whose raison d'être was to make the most of the efforts made and to equip the whole group to embark on new telecommunications technologies. ${ }^{34}$ It included the definition of innovations in services, network architectures and operating techniques, including systems engineering solutions. It closed the list with the development of products

\footnotetext{
${ }^{28}$ Telefónica's memory links the agreements with AT\&T to the promotion of $R \& D$ and the creation of R\&D centres, which are described as rara avis in the Spanish panorama of the time: Conversations of the author with Luis Solana, 9/7/2013 y 8/3/2016.

${ }^{29}$ CTNEM 1985, p. 11

${ }^{30}$ The funds involved amounted to over Ptas. 2,305 million, of which Ptas. 713 million related to investments, a sum equivalent to $0.8 \%$ of operating income, which, although significantly increased with respect to previous years, was much lower than in other countries: El País, 23/10/1983.

${ }^{31}$ In Spain, characterized by the existence of a semi-public monopoly served by Telefónica, by the late 1980 s per capita income and income per access line were among the lowest in Europe, just above Portugal and the countries of Eastern Europe: OECD (1999), pp. 48-49.

${ }^{32}$ CTNEM 1983; CTNEM 1985, p. 40 and CTNEM 1986, p. 32.

${ }^{33}$ At that time, two organizations emerged with the intention of training technical and research staff in cutting-edge technologies: the Technology Center for Advanced Studies and the Foundation of Training and Technology Centers (1988), this with private and public participation: Libros de Actas del consejo de administración de Telefónica (hereinafter, LACAT), $22 / 5 / 1987$.

${ }^{34}$ It was envisaged as a tool to promote innovation in an environment conducive to the generation of new ideas, the perennial management of change and the assumption of risks inherent in any R\&D\&i process:
}

and systems of strategic interest and the creation of new hardware and software development methodologies. ${ }^{35}$

In comparative perspective, the creation of a central R\&D unit was a common occurrence in other large European countries. Spain differed from the predominant European model because the semi-public nature of the telecommunications operator led to the creation of an R\&D subsidiary dependent on the company's budget, while the UK and France developed public R\&D centres [42]. ${ }^{36}$

Although it was the flagship of Telefónica's research, TIyD did not exhaust the activity in this field deployed by the operator, which also had other subsidiaries in certain segments, including Telefónica Sistemas and its sections, which specialized in system engineering, networks and telecommunications infrastructure. The complete R\&D system at the CTNE included areas as diverse as the development of industrial products of immediate interest in collaboration with suppliers and its own products of technological relevance. It also included advanced developments in search of information to support risk assessment in the specification of new products. Finally, it included applied research for telecommunication techniques in order to assimilate scientific achievements and adapt them to market needs in cooperation with public R\&D organizations, not to mention the immediate tutoring of telecommunication professionals with Latinamerican scholarships. $^{37}$

\section{THE CREATION AND ACCUMULATION OF TECHNOLOGICAL CAPACITY}

TIyD began to consolidate with the immediate definition of its technological orientation. In the previous stage, the CTNE invested $3.3 \%$ of gross capital formation and $4.8 \%$ of sales, figures which supported a demanding industrial R\&D group and the needs of the expanding and modernising service. TIyD attracted university and research staff and external consultants so that, by the end of $1988,72 \%$ of the more than 400 employees were graduates, a proportion which in 1996 stood at three quarters. ${ }^{38}$

The evolution was characterized by the improvement in the provision of infrastructures -, the successive increase of its staff, first to almost a hundred employees and then to 596

Estatutos; CTNEM 1986, p. 35. As opposed to the official dating in 1988, Minute No. 1 of its Board of Directors (21/12/1987) endorses the date of 1987.

35 Telmem 1987. A mixed working group was set up in the prominent MEDAS software project: Levine (1994), p. 289.

${ }^{36}$ Before the $1980 \mathrm{~s}$, the main innovations were fostered by the monopoly telecommunications operators in the respective large developed countries. They concentrated the early stages of research, design and development in their own central research laboratories (AT\&T in Bell Laboratories, Japan's NTT in Electrical Communications Laboratories, BT in Martlesham Laboratories and France Telecom in its CNET Laboratories) [43]. Deutsche Telekom, responsible for all research, joined forces with the Technical University of Berlin in 2005 to create a central R\&D unit -Telekom Innovation Laboratories- [44]

37 Overall, the percentage of companies cooperating with competitors or participating in companies with Techno logical innovation or EU projects did not reach $10 \%$ and $25 \%$ in small and large companies, respectively [30].

38 TIyDActas, 24/10/1988; LACAT, 28/1/1987; Telmem, Balance Social 1984-1985, pp. 145,$156 ; 1986-1988$, p. 134; 1985, p. 11; Telmem 1988, p. 22; ACE, 11/10/1989. CTNE's R\&D amounted to 1,100 million pesetas in 1977 and 5,400 million pesetas in the two-year period 1986-1987: ElP, 24/6/1978; Telmem, Balance social 1986-1988, p. 133. 
towards the end of the decade, and, thirdly, the increase in the weight of research in the total activity. ${ }^{39}$

TIyD started by acquiring knowledge of digital telecommunication systems and pulse code modulation. This was followed by the development of an experimental broadband network, a high-capacity, high-speed Internet access and data transmission channel. It also began work on identifying services for the ISDN (Integrated Services Digital Network) and on attracting customers to provide them. The stage culminated in 1995 with the participation in the development of Infovía, the first widespread Internet access service in Spain based on the IP [45]. ${ }^{40}$

Attention to switching denotes the composition of Telefónica's R\&D\&I expenditure and investment. In 1982 switching was the largest item, followed at a distance by transmission and subscriber equipment, according to a product innovation orientation. When digitalisation was at its peak, a major challenge lay in reducing operating costs and improving quality. The CTNE entrusted TIyD with the task of modernising electromechanical fixed-line systems with digital-capable exchanges. The MORE Attention to switching denotes the composition of Telefónica's R\&D\&I expenditure and investment. In 1982 switching was the largest item, followed at a distance by transmission and subscriber equipment, according to a product innovation orientation. When digitalisation was at its peak, a major challenge lay in reducing operating costs and improving quality. The NECC entrusted TIyD with the task of modernising electromechanical fixed-line systems with digital-capable exchanges. The MORE (MOdernización de Registradores Electromecánicos) electronic recorder, a development applied to pre-existing analogue telephone exchanges, allowed detailed billing through multi-frequency dialing from user terminals, detailed call recording and expanded numbering electronic recorder. ${ }^{41}$

In addition, the operator promoted advanced switching, with a view to improving network operation and efficiency and diversifying the range of services offered to subscribers. In 1981, AXE-type digital exchanges enabled progress to be made in the implementation of the automatic telephone service in vehicles. However, tactical reasons - to extend the life of the equipment - and financial reasons - to shorten the payback time of the investment in the new facilities - led to the extension of the non-border switching - semi-electronics. To the tune of digital switching, large manufacturers invested heavily in particular systems: Ericsson developed the AXE and IT\&T in cooperation with System 12 and its variants. The initial definition of the latter included studies for the introduction and optimization of Integrated Digital Networks, for which the IT\&T group had worldwide responsibility. In addition to the local capacity represented by two groups of engineers from CTNE and SESA, training was also provided in centres abroad. ${ }^{42}$

The implementation of the COBMAIN and ATME auxiliary conservation equipment and the development of new possibilities with external technological support continued. Challenged by the isolation of the most remote rural communities, the CTNE developed the MAR (Multiacceso Rural) system, which enjoyed, along with some technological achievements, a favourable commercial reception in Spain and in various foreign markets. ${ }^{43}$ The developments were extended to support the management and operation of the telephone network with the Operation and Conservation Structure (Estructura de Operación y Conservación, EOC) $)^{44}$ whose gradual introduction into the facilities meant an intensification of the effort to optimize functionality and reduce costs. Of great interest, the cooperative scheme led to specific developments by some of the Telefónica Group companies. $^{45}$

In tandem with that of Telefónica Sistemas, the TIyD activity was able to cover up the shortcomings of suppliers and enjoy autonomy from them in strategic areas. One of the most remarkable outcomes is the generation of a highly diversified portfolio of technological industrial and intellectual property in the areas of telecommunications, in which trademarks clearly predominated over domain names (Fig. 4). At the beginning of the new millennium, the Telefónica Group's patents and models on intellectual property registries $(1,541$ and 1,058 , respectively) were also clearly dominant. This technology portfolio provided the channel to assimilate and control the characteristics and evolution of the different technologies, differentiate itself from the competition and diversify supplies. ${ }^{46}$

department (José Pozas, 17/12/2018) and to the inter-company cooperation of IT\&D with a subsidiary of Amper: Amper, Memoria anual 2000 [sp].

${ }^{42}$ Author's interview with Ignacio Menéndez de Luarca, 28 October 2019.

${ }^{43}$ CTNE and SESA engineering groups received training in the USA: Author's interview with Juan Mulet Melià, 16 May 2013. Several Latin American countries - Argentina, Bolivia and Nicaragua, among others acquired equipment from MAR:

44 Telmem 1988, p. 22. The Switching Programming Center (Centro de Programación de Conmutación, CPC), an organic unit equipped with the various stored program control systems implemented by CTNE, supported the management of advanced switching software. Castells [47] attributes to it the objective of achieving sufficient capacity to deal with two major issues: solving the problems of maintenance of electronic exchanges with autonomy from suppliers and dealing with value-added networks and the operation of the Integrated Business Communications Service (Comunicaciones de Empresa, SICE).

${ }^{45}$ Telmem 1989, pp. 17-19. As opposed to major international competitors (AT\&T and CGE), EOC was adopted by companies of the group, among them the Chilean CTC, which contributed to specific developments (Actas de Telefónica de Chile -ACTCH, 15/1995), in accordance with the aforementioned intra-company mobility of technology in multinationals.

${ }^{46}$ Telmem 1993, pp. 32-34 y 1994; Telefónica, S.A. (2003), p. 27. In 1993, Telefónica reached a total of 1,092 industrial and intellectual property titles, an amount that grew to 1,142 the following year: Telmem 1993, pp. 32-34 and 1994. Telefónica was very inactive in the United States, where it obtained only 17 patents between 1995 and 2001: OECD (2009), p. 93. In a 


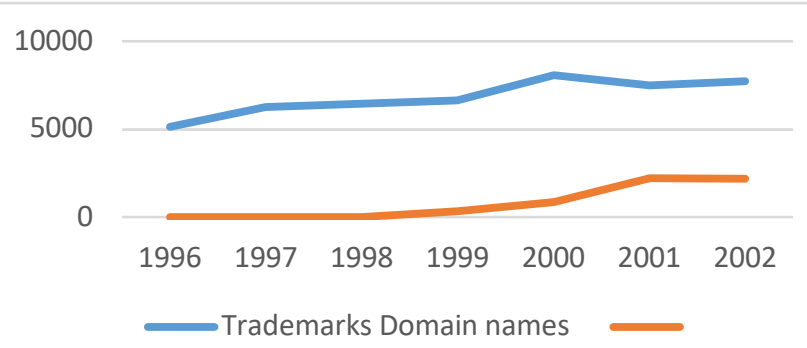

Fig. 4. Telefónica: Industrial and intellectual property portfolio Source: Own from Telefónica S.A., Informe Anual de Responsabilidad Corporativa 2002, p. 15.

Over time, Telefónica imposed changes in orientation and guidelines to achieve centralized control instruments. In the organisational sphere, the headquarters formed an R\&D Committee, in which the group's senior management participated. As part of its market orientation, it sought to increase the business of its subsidiaries outside the parent company to a level of $0.5 \%$ in the case of IT and R\&D. The relationship between CTNE and its subsidiary was conducted through the Technology and Technical Regulation department. This subsidiary also considered focusing on the most strategic and innovative projects, those in which it could play an irreplaceable role. ${ }^{47}$ Indeed, it concentrated on those that decreased the operator's costs or increased turnover, especially the aforementioned Infovía and the CPSA (Centre for Advanced Services Provider). On the other hand, the automation of information services allowed savings of half a thousand switchboard operator positions, the development of prototypes for Telefónica Móviles and dedication to promotion activities.

In $1999-2000$, TIyD's activities grew by $30 \%$ and $20 \%$, respectively, with respect to the previous year. The subsidiary added new IP network services, notably ADSL access, a new high-capacity mechanism, to its information services in general and to the Internet in particular. Special emphasis was given to the increase of value added services through new card facilities, billing and consumption information, among others. It also sought to boost customer services with new information facilities and the availability of advanced call centres for SMEs. ${ }^{48}$ In essence, its activities were carried out along four main lines, which included the development of activities focused on optimizing business processes, new services that set it apart from its competitors, network management systems and the so-called Innovation Program,

context of scarce information on patents, in 2002 Telefónica's portfolio consisted of 2,185 patents and models, 735 intellectual property records, 2,182 domain names and more than 7,700 registered trademarks: Telefónica S.A. (2002), p. 60; 2004 gives the following figures: more than half of patents (1,787 out of a total of 3,032 registrations), intellectual property rights $(1,245)$, mainly software developments; in 2004, TIyD patented 240 new products developed during the last financial year: Telefónica S.A. (2004), pp. 43 y 26 .

47 ActasTIyD, 29/10/1992 TIyDActas, 28/4/1988 y 20/10/1989.

${ }^{48}$ Telefónica, S. A., Informe Anual 1999, pp. 63-64.

${ }^{49}$ Telefónica, S. A. Informe Anual 2000, pp. 69-70. In 2005, ITyD had five Centers, two located in the largest cities in the country -Barcelona and Madrid-, and three in more modest ones - Huesca, Granada and Valladolid. ${ }^{50}$ TIyDActas, 21/2/1992; 29/10/1992; 18/12/1996; 24/4/1997 and 21/2/1997. ${ }^{51}$ In 1991-1994, the EU allocated 1,552 million ECUs to R\&D programmes of ICTs; the vast majority of these $(96.26 \%)$ went to information technologies, led by basic research $(27.32 \%)$ and information processing systems and software (26.38): Comisión de las Comunidades Europeas (1995), p. 98. in its various services and activities. They also highlighted the transfer to Telefónica Media of the existing IT\&D content development group (ArtMedia) and the consolidation of its new R\&D Center in Boecillo (Valladolid). ${ }^{49}$

At the beginning of the millennium, technological innovation in the Telefónica group was unevenly distributed among various concepts, with a clear predominance of equipment for new products and services $(46 \%)$, a long way from R\&D itself $(26 \%)$, design and production planning and distribution of innovations (13\%) and other knowledge and licences (13\%) (Telefónica S.A., 2002, p. 59).

A specific and careful reference deserves the policy of international alliances. In 1996, as part of a greater focus on marketing, Telefónica promoted joint work with other laboratories in the Unisource strategic alliance, of which it was a member. In a comparative perspective, it is worth emphasizing that TIyD maintained a good position both in relation to activity orientation and in terms of costs in the companies of the alliance. ${ }^{50}$ The approach to TIyD was in line with other R\&D centres, which were keen to increase product development.

Telefónica adhered to the European policy of promoting research and preparing for the single telecommunications market. Not for nothing did it hold the position of first Spanish company by participation in R\&D projects promoted and partially financed by the European Union (EU), the breakdown of which by company does not appear in the published data. ${ }^{51}$ A similar practice was carried out by TIyD, which, by the end of the period studied, was collaborating in more than twenty-five bodies and associations, both national and international. ${ }^{52}$

In 2004, Telefónica reoriented its technological innovation model in order to promote collaboration with various technological allies - customers, public administrations, suppliers, other companies and universities -, improve competitiveness and promote an innovative culture at all levels of the organisation, incorporating employees into the innovation process $^{53}$. A newly created external advisory body came to reinforce this model and to establish a new framework in the development of its R\&D\&i activity. ${ }^{54}$ Quality improvement took organizational form with the creation of an area to attend to the strategic Access Systems and with the activities of network analysis and planning, testing and qualification systems. Different telephone terminal technologies contributed to the same purpose. In the area of applied research, a technological source of cutting-

${ }^{52}$ In 2002 it participated in 37 European IST (European Information Society Technologies) projects and two years later the figure reached 56 European projects, with a committed dedication for the period 2004-2006 equivalent to 225 people and an EU grant of 16 million euros; for its part, it was committed for the period 2004-2008 to 71 projects promoted by the EU, focusing on the areas of new multimedia services, mobile and integrated communications and software solutions: TIyDActas, $10 / 7$ and 29/10/1992; 20/6/1996; Telefónica S.A. (2002), p. 60; Telefónica, S.A. IT\&D activities in EU initiatives aimed at promoting $R \& D$ were organised through three European technology platforms: eMobility, NEM (Networked Electronic Media) and NESSI (Networked European Software and Services Initiative): Telefónica, S.A. (2005). p. 12; Telefónica S.A. (2002), p. 60

${ }^{53}$ Telefónica, S.A., Informe anual, 2004, p. 40.

54 This was the Scientific Advisory Board of Telefónica I+D, made up of prestigious personalities from the business, scientific and public administration worlds, from the various regions and areas in which the Telefónica Group was present. Its task focused on contributing to the generation of new ideas, identifying the most relevant elements in the scientific-technological evolution of ICTs and formulating recommendations for the Group of Telefónica, S.A. (2005). p. 12. 
edge solutions, work on the treatment of speech achieved experimental developments. ${ }^{55}$

\begin{tabular}{cccc}
\multicolumn{4}{c}{ TABLE I: TELEFÓNICA'S INVESTMENTS (MILLIONS OF PESETAS) } \\
\hline Year & 1 Material & 2 Immaterial & $\mathrm{c}$ Total \\
\hline 1982 & 150704 & 1515 & 152219 \\
1983 & 164404 & 1658 & 166062 \\
1984 & 173642 & 1607 & 175249 \\
1985 & 188681 & 1778 & 190459 \\
1986 & 211514 & 1866 & 213380 \\
1987 & 260183 & 4398 & 264581 \\
1988 & 375815 & 6234 & 382049 \\
1989 & 583762 & 5380 & 589142
\end{tabular}

Source: Based on Telefónica, Annual Report(s).

In short, what shaped Telefónica's own innovation system? Traditionally, Telefónica led the ranking of Spanish companies with the greatest dedication of resources to research and development.

We know more details of the innovation model for the final period of this study. The operator represented around $7 \%$ of the national private $R \& D$ investment and $24 \%$ of the investment in innovation of the ICT sector in Spain. Taking a specific year, in 2003 Telefónica allocated $1.7 \%$ of its revenues to R\&D in Spain, a figure clearly higher than the percentage of R\&D as a percentage of GDP for the country as a whole (1.1\%), which allows us to attribute the promotion of Spanish R\&D to the operator.

If we move from the parent company as a whole to the specific subsidiary, the structure of IT and R\&D expenditure on research denotes a predominance of that promoted by the subsidiary itself (43\%), a percentage higher than that of the EU $(35 \%)$ and even more than that of the public authorities $(22 \%)$. This behaviour thus puts it on a par with that of private companies as a whole. The development was carried out by IT \& D in similar proportions $(45 \%)$, as well as by other external companies and directly from the business lines in smaller proportions ( $40 \%$ and $15 \%$ respectively). The breakdown by business lines was led by Telefónica Móviles (53\%), followed by Telefónica España $(25 \%)$, Telefónica Latinoamérica $(15 \%)$ and others (7\%). By concept, innovation was unevenly distributed and led by the teams, followed at a distance by $R \& D$. In the development of software for new products and management systems, the greatest weight was given to products and services (47\%), followed by business management $(27 \%)$ and infrastructure management (26\%) (Telefónica, S.A. (2004), pp. 7, 20-27, 40-41). ${ }^{56}$

Most likely, what defined the company's R\&D was the size of the investment and its destination (TABLE I). Let us first consider the total investment in its material or fixed and immaterial capital variables, the sum of $R \& D$ expenses,

\footnotetext{
${ }^{55}$ These included the fixed and variable message informant, applications to voice recognition techniques and an interactive station for recording messages. The processing of images led to the development of a specific station, also suitable for the simulation of coding techniques: Telmem 1985 pp. $17-18$.

${ }^{56}$ During 2004, the operator invested nearly 2.4 billion euros in technological innovation, $19.6 \%$ of which was in specific R\&D activities and $41 \%$ in equipment: Telefónica, S.A. (2004), p. 42; in 2005, 1.4\% of the Telefónica
}

software licenses and others. Driven by the boom in diversified demand and technological change, between 19821992, total investment almost quadrupled (x 3.87). The discrepancy in the strength of this growth between the two variables - tangible and intangible - reinforced the weight of the former. The trend was broken in the following decade because, after declining for much of the 1980s, intangible investment intensified and upset the relationship between the two. This ratio between intangible fixed assets, composed primarily of R\&D expenditure, and tangible fixed assets, an indicator of R\&D intensity, began a significant growth path (Fig. 5).

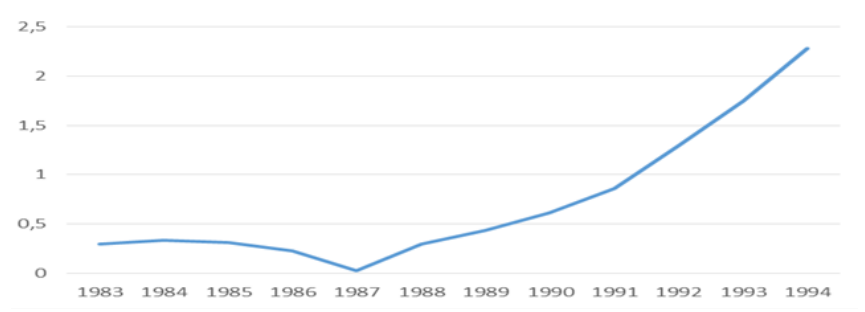

Fig. 5. Intangible/tangible assets at Telefónica (\%)

Source: Own from Telefónica, Memoria(s) anual(es).

As a fundamental issue, the definition of Telefónica's R\&D system naturally leads to the question of whether it was a model of success.

Firstly, in order to properly evaluate the CTNE/Telefónica system, it is necessary to take into account its dual role as a promoter of industrial $\mathrm{R} \& \mathrm{D}$ due to its participation in an industrial holding company for telecommunications equipment and its significant weight in the total R\&D carried out in Spain. ${ }^{57}$

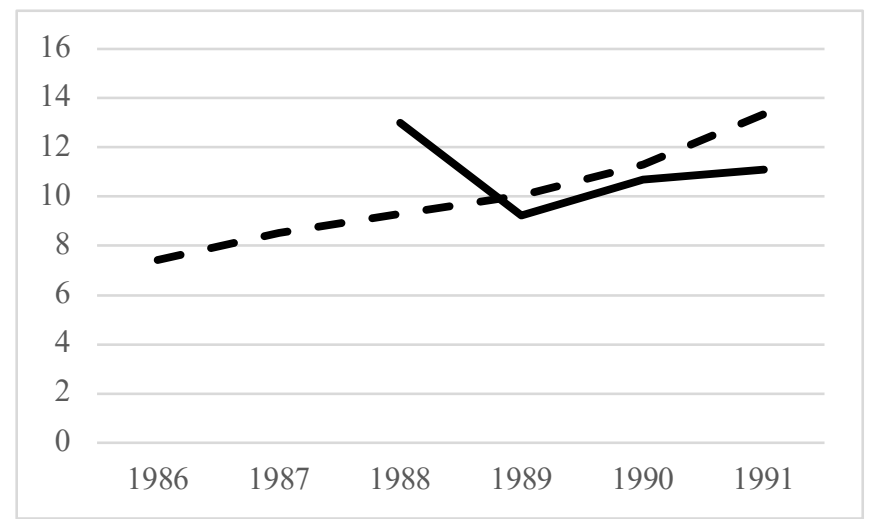

Fig. 6. Productivity of Telefónica and Telefónica I+D (millions ptas./employee)

Source: Elaborated from TIyD, Annual Report(s).

Secondly, the company was clearly optimistic about the profitability of its R\&D activities. ${ }^{58}$ This appreciation was corroborated by the upward curves of productivity and efficiency, measured by the relationship between income and

Group's total revenues were allocated to R\&D: Telefónica Móviles España (2005), p. 23.

${ }^{57} 4.9 \%$ of total R\&D and $9.4 \%$ of business R\&D: Telefónica S.A. (2002), p. 53.

${ }^{58}$ Key facts: public telephony system sold to 16 countries, royalties of around 800 million pesetas and $40 \%$ increase in average turnover in public telephony; Infovía service: revenue of 1,400 million pesetas in 1996 to the benefit of Telefónica; cost savings for the operator due to automation of national reverse charge or call handling: TIyDActas, 18/12/1996. 
number of employees (Fig. 6) and between active projects and employees, respectively.

The first almost quadrupled in 1988-2000 and the second multiplied by more than eight. ${ }^{59}$

Telefónica's R\&D was highly valued. Given the overwhelming predominance of TIyD sales to the Telefónica group, the subsidiary's degree of success was conditioned by the results of the parent company, as well as by the parent company's accounting guidelines and standards. In addition to the above-mentioned requirement to increase the business of subsidiaries outside the parent company, a notable example of guidelines in the case of TIyD was the requirement to purchase all CTNE's technology at the minimum values indicated in the business plan for which TIyD services would receive a fixed annual amount. This could be a cost diversion from the parent company to the subsidiary.

Indeed, although the parent company's specific R\&D tool, TIyD tangible assets were less than $1 \%$ of the Group's total. The structure of the IT and D customers was based on the overwhelming predominance of the Telefónica Group, which accounted for more than $98 \%$ of the Ptas. 12,781 million contracted according to figures for the end of 1998. The breakdown by Telefónica units showed a preponderance of Commercial $(52.42 \%)$, followed by Infrastructure $(18.95 \%)$, while contracting with other subsidiaries of the Group placed Telefónica Móviles at the head and Telefónica Data at the bottom. Telefónica International participated in contracting with $9 \%$ and Telefónica Media with $1.56 \%$. Banks and telecommunication equipment companies - Argentaria, Lucent and BBV - were the minority external customers. ${ }^{60}$ In the balance, you have to include the problems. To start with human capital, TIyD dragged along a high turnover of staff. In this area, the level in R\&D centres abroad was $10 \%$ and between 4 and 5 years the usual permanence of new recruits in the centres, with subsequent incorporation of a large number of them into the business operation. ${ }^{61}$

To continue with some of the developments, the TESYS B, undoubtedly the star product, became a 'delicate project' due to the decision to adopt alternative packet switching equipment in some of Telefonica's own services. ${ }^{62}$

Doubts are also raised by the vicissitudes of optoelectronics, one of the privileged lines from the beginning along with microelectronics on the advice of Bell Communication Research (Bellcore). Its continuity was soon discussed and accepted with reservations in order to avoid damage to the entire innovation process. However, the subsidiary, in agreement with the parent company, soon abandoned the optoelectronic activity because of the worsening market prospects, trying to transfer the non-reusable assets to others with the capacity to use and maintain them. This is not a minor issue due to the high investment required by some infrastructures - clean rooms - which are very rare in Spain. ${ }^{63}$

\footnotetext{
${ }^{59} \mathrm{TIyD}$, Informe(s) anual(es).

${ }^{60}$ TIyDActas, 27/5/1999. For example, in 2001, developments contracted with Telefónica R\&D amounted to approximately half of the EUR 130 million invested in R\&D by Telefónica Móviles [48].

${ }^{61}$ TIyDActas, 30/9/1996. Workforce turnover: $19.03 \%$ in 1990: TIyDActas, $31 / 10 / 1990$; the main reasons given included salary, geographical and service provision in the area of other companies: TIyDActas, 31/5/1990. Example of employee turnover or exit from the company, in Ericsson Spain, turnover percentages ranged from 8 to $14 \%$ at the end of the 1990s: Ericsson, Memoria, 1990, p. 4.

${ }^{62}$ This is what happened at the UNO network: TIyDActas, 14/5/1992. At the outset of 1991, the TESYS B had taken up a quarter of the company's total resources: TIyDActas, 8/2/1991.

${ }^{63}$ TIyDActas, 4/4/1990 and 26/5/1994.
}

What has occurred with some developments originally intended to meet urgent demands from Telefónica, including the MORE project, allows us to draw interesting lessons. Here two perspectives confront each other. The creators claim their opportunity to solve Telefónica's bottlenecks and its high profitability for the operator, not without recognising short-term effects and loss of the experience and knowledge accumulated in the design and implementation of the system. ${ }^{64}$ ITyD and its environment blamed the MORE project for its short-termism and, in fact, the equipment of this technology soon became obsolete and was cornered by the digital ones of the big multinationals. The obsolescence lay in the actual conception of the technology but also in notable alterations in the times established for its development and delivery. In addition, there were delays due to changes in the project profile due to successive inclusion of services, as well as to the reluctance of Telefónica itself and difficulties in the immediate availability of adequately trained external personnel and the supply of components -hybrids- by regular suppliers -Amper. ${ }^{65}$

Far from being unique to the MORE, the problems also affected the TESYS development projects, modular telephones and the Operation and Conservation Structure. The inefficiencies extend to the management of human resources, which are subject to an obligatory transfer of the creations to Telefónica, but are to a large extent subject to a high rate of abandonment for salary reasons, among others, and, in short, wasted. This is partly the same as what has been said for the bodies that specialise in promoting technological development in Spanish industry, including the CDTI.

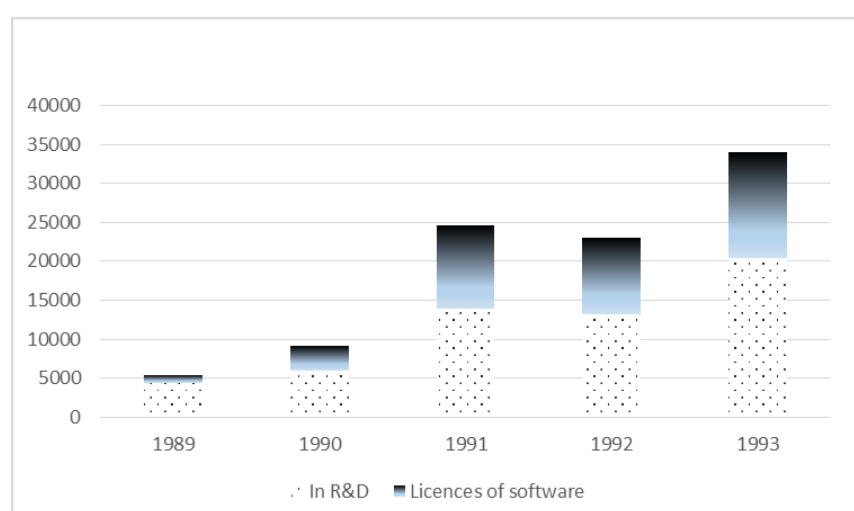

Fig. 7. Composition of intangible assets

We can go a little further in this direction if we look at the composition of intangible assets (Fig. 7). Here, R\&D expenditure, precisely the asset with the greatest potential for growth and a real lever for competitiveness, was unequivocally reinforced in the 1990s and overtook expenditure on software licences. This is a fundamental

\footnotetext{
${ }^{64}$ The completion of the project led to the disintegration of the group, except for a minimal part for maintenance: Mariluz Congosto, Personal communication to the author, 2 December 2018. According to Congosto (2018, pp. 12 and 14), MORE was a solution to the early obsolescence of the switching plant, an example of how Telefónica's R\&D and Spanish industry could compete with the telecommunications multinationals, a strategic lever that facilitated the digitalization of the network and, finally, a platform to automate the maintenance of other digital systems (OMEGA).

${ }_{65}$ Author interview with Juan Mulet Melià; TIyDActas, 27/9/1991 and 29/4/1993; among other features added, there is detailed billing: TIyDActas, $21 / 2 / 1992$. Telefónica tried to attract technicians trained in other companies, including GTE Electrónica, which specialises in small capacity radio links and is a competitor of Telettra.
} 
feature that distances itself from the national innovation model, which is more likely to subordinate R\&D investment to licensing expenditure. The idiosyncrasy of the case also points to a path of relative success that the national economy did not emulate. Taking the growth rate of gross value added as an indicator, it is easy to note that it exceeded the national rate, although with a slight deceleration. Even recognizing the weakness of the indicator in the face of the impossibility of attributing the responsibility for the variation in it to $R \& D$ activity, it can be estimated as a component of the relative success of the Telefónica formula.

The book value of TIyD at Telefónica remained stable within a trend of growth in the parent company's total book value, and therefore its relative weight was reduced. Ultimately, there is a lack of decisive data to reach clear conclusions. In the Annual Report, Telefónica did not break down the revenues of its TIyD subsidiary, which were included under the heading "other subsidiaries or inter-group sales". However, other sources provide information on an ad hoc basis. In the first stage of TIyD, the self-rated stage of creation and growth, revenues were multiplied by 8.86 in current pesetas. In the second stage, which coincided with the dot.com bubble, there was sustained growth, which gave way to practical stagnation in the self-qualified stage of Open R\&D (Telefónica Investigación y Desarrollo, 2008, p. 8).

An examination of Fig. 6 forces us to qualify the observations derived from the increasing technological intensity. In the first years of life, the productivity of the TIyD subsidiary generally remained below that of the parent company and the trend was towards an increase in distance. According to this, TIyD would not have acted as a spur but as a hindrance. Such a statement largely contradicts several points made above and deserves to be commented on.

Let's take as an indicator the weight of high content R\&D activities in the Telefónica Group's operating revenues (digital exchanges, intelligent network, ISDN and IBERCOM). The data available show a significant increase throughout the nineties. For its part, the more than doubling of sales of the star product TESYS between 1988 and 1992, much of it in the international market, points to a relative success, which would increase if we consider that the fruits are not measured only in terms of direct business but by its core effects ${ }^{66}$. Nor is it appropriate to limit ourselves to quantitative aspects. The TESYS not only opened up the world market to Telefónica but also provided it with a platform for establishing international alliances with technology leaders, such as the one forged with the American company Electronic Data Systems to develop, market and install data transmission networks ${ }^{67}$.

The weaknesses of the model are accentuated in some international comparisons, which, despite the positive symptoms, do not leave the Spanish operator well off. In 1987, Telefónica was in an almost leading position in terms of investment behaviour, measured by the ratio of investment to revenue. By the end of the 1990s, Telefónica had fallen back to fifth place among the major world operators in terms of the volume of R\&D expenditure, behind Japan's NTT, BT,

\footnotetext{
66 The TESYS equipment installed abroad accounted for $28 \%$ of those installed in the IBERPAC Network in Spain; contracts for the development of data transmission networks in Colombia, USA, Canada, UK and Tunisia: Actas de Telefónica Internacional (Minutes of Telefónica Internacional, ACTISA), 17/4/1986. The weight of the TESYS system in the company's total volume had almost doubled from $13.7 \%$ in one year (1982-1983): Diario de Sesiones del Parlamento de Andalucía, 22 January 1983.
}

France Telecom, Deutsche Telekom and Sweden's Telia Sonera. Furthermore, its position was worsening - seventh position - in terms of the proportion of R\&D expenditure to total revenues (Appendix I). Only the bursting of the dot.com bubble altered this situation in favour of Telefónica, which was less indebted than the other companies because of the huge expenditure on spectrum licences for the deployment of third-generation mobile telephony (UMTS) [49].

The globalization of telecommunications had as a corollary the internationalization of $R \& D$ in various aspects, including agreements and alliances and foreign direct investment as greenfield investment. To begin with, one of the pieces that introduced the innovation system of the IT\&D company was the participation of foreign multinationals in the design of organic R\&D units: Pacific Telesys, one of the regional babies broken up from AT\&T after its dismemberment and, at the same time, a supplier of data transmission equipment TESYS ${ }^{68}$.

Finally, the geographical distribution of R\&D at the end of the period showed a clear predominance of Spain, although with a downward trend.

\section{CONCLUSION}

The analysis of the high-tech industries in the chosen years means facing profound transformations on the world scene, which largely shaped the current situation. They include technological change, market liberalisation, privatization of state monopolies - semi-public in the case of Spain - and the decomposition of the oligopolistic structure in the equipment industry.

Within a debate of extraordinary significance at present, the article has mainly embraced the system approach of complex relationships among actors rather than the linear view. It has examined strategies for the creation and accumulation of local R\&D capabilities in advanced sectors, along with some explanatory causes for the limited success achieved. It depicts Spain as a peripheral country facing the challenge of competitiveness imposed by the double process of integration into the European economic area and the growing globalisation of the economy. It does so from a dual macroeconomic and business history perspective - the case of Telefonica - in an area where it meets the applied economy in general, economic history and strategic management. This is where the involvement of various components - national and international; company strategies; inter- and intra-company transfers of technology - appears in an era sealed by globalisation.

The historical analysis of business R\&D in the country is of great interest in itself, but the study of one of the largest and most internationalized Spanish companies increases this interest. It is especially important to see how Telefónica is coming into contact and collaborating with foreign multinationals in the sector and how it is catching up with new communications technologies.

The article, structured in three blocks, shows unquestionable efforts deployed to get out of the situation of technological dependence. These attempts have proved to be insufficient,

\footnotetext{
${ }^{67}$ Electronic Data Systems (EDS) relied on the Tesys in its global network; EDS had recently been strengthened by its alliance with General Motors: Network World, 21/9/1987, p. 9.

${ }^{68} A C E, 3 / 11 / 1982 ; L A C A T, 27 / 3 ; 30 / 4 / 1985$. The Italian company STET went further in the collaboration and, through a subsidiary, agreed with Bellcore to establish a joint laboratory in Turin.
} 
however, judging by the insistence that even at the beginning of the 21st century analysts place on the relative backwardness of strategic technologies and the need for state pacts for innovation, reindustrialization and education. Even today, just over a quarter of Spanish companies are innovative and only $0.32 \%$ of SMEs do R\&D. It is not enough for a country to put together the components of a modern innovation system; it must be properly managed and funded and have the appropriate replication mechanisms.

Special attention has been drawn to issues of the internal organisation of the innovation process and the organisational shaping of research or formalisation, in short. Primarily, it has brought to light differentiated business strategies that include the most elementary stages -the research center- and the deepening of the formalization of $\mathrm{R} \& \mathrm{D}$, with the creation of a company detached from the matrix in the case of IT\&D. This is distinguished by its status as a semi-public company not dependent on the general state budget; it is also distinguished by a purely chronological aspect, since it was created towards the end of the 1980s, whereas some companies linked to public telecommunications monopolies dated back many years. Can we talk about centralisation of R\&D in the case of Telefónica? Evidence shows that operators responded differently to the need for $R \& D$ and that the centralized model in the operator, the centralization in the subsidiary and the mixed model, represented by Telefónica, coexisted.

Telefónica represents the effort to change its relationship with the telecommunications equipment market through an industrial holding company of second suppliers according to a vertical integration formula to try to reduce its dependence and gain flexibility in supplies. In compliance with the European Union's guidelines on the liberalisation of telecommunications and the creation of a single market, the operator was forced to divest itself of industrial assets. It is practically at this point that it begins an outward orientation as an operator and creates TIyD.

Some of the results of this subsidiary, which are markedly different from those of the national economy as a whole, escape 'third world' thinking and point to differential performance. IT\&D combined the commitment to strategic frontier technologies with the maintenance of obsolete technologies and pragmatic solutions to economic problems. However, in the semi-public monopoly operator, foreign solutions finally triumphed in some of the star developments, as happened with the TESYS, or other advanced lines had to be abandoned, such as the optoelectronics projects or the development of MORE switching equipment. Undoubtedly, these are investments accounted for in advanced technology that were applied and generated benefits. However, these investments can hardly be considered as fully productive and with lasting effects due in part to loss of the human capital gathered in the design and implementation of the system. This would prove the non-linear nature of the accumulation of technical skills in companies, a central aspect of this study. We are therefore closing the circle of the continuity of Spain's technological dependence that continues to this day and is hampering economic growth.

Having said that, it is worth highlighting the extreme difficulty in capturing the results of innovation projects, relations and international meetings in which Telefónica participated in the 1980s and 1990s. The same applies to human resource qualification policies and international alliances. A tentative assessment points to a strengthening of the presence as a supplier of products in the markets already conquered and to the expansion to others in the respective areas, be it Latin America or Asia. More significantly and of greater importance, it also aims at establishing the basis for the configuration of the distinctive character of Telefónica as a multinational company.

In closing, it is clear that monographic studies of the companies mentioned here, sometimes very difficult to carry out due to the lack of sources, would give a more perfect panorama of business R\&D in Spain.

\section{APPENDIX}

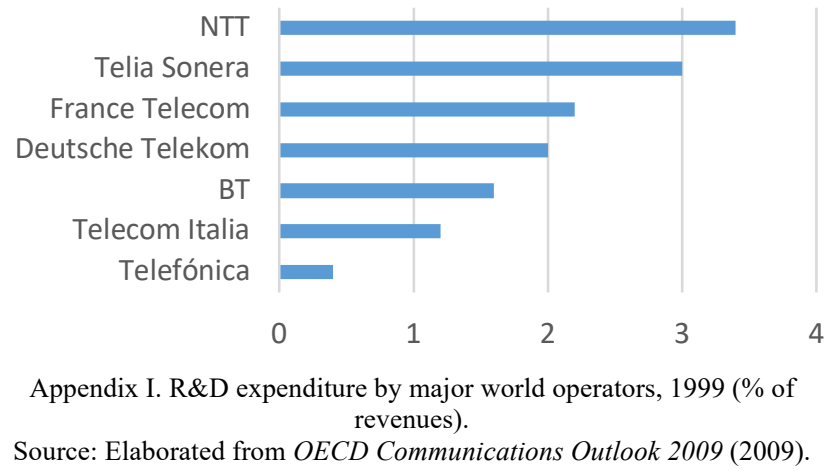

\section{ACKNOWLEDGMENT}

This study is assigned to the Centre d'Estudis 'Antoni de Capmany' d'Economia i Història Econòmica, Departament d'Història i Institucions Econòmiques, Facultat d'Economia i Empresa (Universitat de Barcelona). I would like to thank those responsible for supporting my research. I would like to thank those responsible for supporting my research.

\section{REFERENCES}

Oral source (Interviews and communications)

Author's conversations with Luis Solana, 9/7/2013 and Madrid, 8/3/2016. Interview by the author with Joan Majó, Barcelona 17 September 2015. Interview by the author with Juan Mulet Melià, 16 May 2013. Interview by the author with Ignacio Menéndez de Luarca, 28 October 2019.

Interviews by the author with Luis Lada, 22/5/2013 and 17/6/2013.

Personal communication from Mariluz Congosto to the author, December 2,2018 .

Origin of primary sources

Minutes of the Executive Committee of Telefónica (ACE), Madrid. Minutes of Telefónica de Chile (ACTCH).

I.N.I. Historical Archive, Madrid.

Minute Books of the Board of Directors of Telefónica (LACAT), Madrid. Minutes of the Board of Directors of Telefónica I+D (TIyDActas), Madrid.

\section{REFERENCES}

[1] OECD, OECD Communications Outlook 1999, Paris: OECD, 1999, pp. 9, 11-12.

[2] Ph. N. Cooke, P. Boekholt, and F. Tödtling, The Governance of Innovation in Europe: Regional Perspectives on Global Competitiveness, London-New York: Cengage Learning EMEA, 2000, p. 3.

[3] Ph. Gummett, Globalization and Public Policy, Cheltenham: E. Elgar, 1996, p. 173. 
[4] A. Watkins, and M. Ehst (eds.), Science, Technology, and Innovation Capacity Building for Sustainable Growth and Poverty Reduction, Washington: The World Bank, 2008, p. 5.

[5] OECD, National Innovation Systems, Paris: Organisation for Economic Co-operation and Development Countries, 1997.

[6] J. E. Jankowski, Jr., and J. R. Gawalt, National Patterns of $R$ and D Resources (1994), Arlington: National Science Foundation, 1996.

[7] J. Molero, "Foreign technology in the Spanish economy," Research Policy, Volume 12, Issue 5, October 1983, pp. 269-286.

[8] M. Buesa and J. Molero, Innovación industrial y dependencia tecnológica en España, Madrid: Eudema.

[9] D. Uzunidis, and S. Boutillier, "Globalization of R\&D and network innovation: what do we learn from the evolutionist theory?," Journal of Innovation Economics \& Management, 2012/2, 10, pp. 23-52.

[10] O. Gassmann, and M. Zedtvitz, "Organization of industrial R\&D on a global scale,” R\&D Management, 28, 3, pp. 147-161, 1998, pp. 147161.

[11] W. Lazonick, "Learning and the Dynamics of International Competitive Advantage," in Ross Thomson (ed.), Learning and Technological Change, Houndmills: Macmillan, 1993, pp. 172-197.

[12] R. S. Hymer, The International Operations of the Firm, Cambridge MAS: The MIT Press, 1960.

[13] P. Buckley, "Business History and International Business," Business History, 51, 3, 2009, pp. 307-333.

[14] G. Jones, Multinationals and global capitalism from the nineteenth to the twenty-first century, Oxford: Oxford University Press, 2005.

[15] J. Narula, and J. H. Dunning, "Multinational Enterprises, Development and Globalization: Some Clarifications and a Research Agenda," Oxford Development Studies, Volume 38, Issue 3, 2010, pp. 263-287.

[16] J. Narula, and J. H. Dunning, "Multinational enterprises, development and globalization: some clarifications and a research agenda". In: C Pietrobelli, and Rasiah, R. (eds.), Evidence-based development Evidence-based development economics: essays in honor of Sanjaya Lall, Kuala Lumpur: University of Malaya Press, 2012, pp. 19-40.

[17] S. López, and J. Molero, "Innovación e internacionalización en las empresas españolas de componentes para telecomunicaciones un estudio de caso," in Durán, J. J. (coord.), La empresa multinacional española. Estrategias y ventajas competitivas, Madrid: Minerva, 2005, pp. 197-226.

[18] M. Cebrián, "La regulación industrial y la transferencia internacional de tecnología en España (1959-1973)," Investigaciones de Historia Económica, 3, pp. 11-42, 2005.

[19] S. López, "Un sistema tecnológico que progresa sin innovar. Aproximación a las claves de la Tercera Revolución Tecnológica en España," Ekonomiaz: Revista vasca de economía, 22, pp. 30-55, 1992.

[20] J. P. Sáiz, Invención, patentes e innovación en la España contemporánea, Madrid: OEPM-MIE, 1999.

[21] Á. Calvo, Historia de Telefónica: 1976-2000. Las telecomunicaciones en la España democrática, Barcelona: Ariel/Fundación Telefónica, 2016, p. 357.

[22] Comisión Interministerial de Ciencia y Tecnología, Memoria de actividades de I+D: 1996, Madrid: CICYT, 1998, pp. 32-33.

[23] Á. San Segundo et al., Cómo proteger los derechos de Propiedad Industrial e Intelectual en el Sector TIC, Madrid: Fundación Escuela de Organización Industrial, 2007, p. 29.

[24] S. López, "Economía y política del cambio tecnológico," in Á. Calvo, Historia de Telefónica: 1976-2000. Las telecomunicaciones en la España democrática, Barcelona: Ariel/Fundación Telefónica, 2016, pp. 159-180.

[25] J. Molero, and M. Buesa, Economía industrial de España organización, tecnología e internacionalización, Madrid: Civitas, 1998, pp. 161-176.

[26] National Research Council, Government-Industry Partnerships for the Development of New Technologies, Washington: National Academies Press, 2003.

[27] Banco de España/Banco de Francia, Estudio comparado de las empresas industriales francesas y españolas (1991-1999), Banco de España, Madrid, 2002, p. 154.

[28] L. Sanz, El sistema español de investigación: Tendencias y escenario de crecimiento hasta 2015. CSIC, Working Document 04-04, 2004.

[29] J. Mulet, "Una visión empresarial del sistema español de innovación," Economía Industrial, 354, pp. 25-36, 2003.

[30] SEPI, Encuesta sobre Estrategias Empresariales en 2000, Madrid: Fundación Empresa Pública. SEPI, 2001.
[31] J. Molero, and M. Buesa, Economía industrial de España: organización, tecnología e internacionalización, Madrid: Civitas, 1998, pp. 161-176.

[32] OECD, Internationalisation of Industrial R\&D: Patterns and Trends, Paris: OECD, 1998.

[33] OECD Science, Technology and Industry Scoreboard 1999 Benchmarking Knowledge-based Economies: Benchmarking Knowledge-based Economies, Paris: OECD, 1999, p. 121.

[34] R. Narula, and J. Guimón, The $R \& D$ activity of multinational enterprises in peripheral economies: evidence from the EU new member states, Maastricht: United Nations University, 2010.

[35] Á. Calvo, Standard Eléctrica y la industria de las telecomunicaciones en España, 1877-1975, Barcelona: Ariel, 2014, p. 238.

[36] CICYT, Centros de investigación en España, Ministerio de Educación, Madrid: 1990.

[37] U.S. Congress, U. S. Telecommunications Services in Europe, Washington: Office of Technology Assessment, 1993, p. 77.

[38] Ericsson España, Memoria de Actividades año 1990, Madrid: Ericsson España, 1990, pp. 6-7.

[39] Á. Calvo, "Consolidation and rationalization of the public companies in Spain: the information and communication technologies (ICT) holding," Journal of evolutionary studies in business, Vol 4, No 1, pp. 143-179, 2019.

[40] Á. Calvo, "Sector privado y sector público en la industria española de alta tecnología: Indra," Biblio $3 W$. Revista Bibliográfica de Geografía y Ciencias Sociales, 24, 2019a.

[41] Á. Calvo, "Multinacionales, Estado y empresa semipública en la industria de tecnología avanzada durante la década de 1980: ATT y la CTNE," Investigaciones de Historia Económica, 13, 1, 2017, pp. 5162.

[42] A. A. Huurdeman, The Worldwide History of Telecommunications, New Jersey: John Wiley \& Sons, 2003.

[43] M. Fransman, Innovation Ecosystems: Increasing Competitiveness, Cambridge: Cambridge University Press, 2018, p. 81.

[44] Science-to-Business Marketing Research Centre, Case 28 Telekom Innovation Laboratories, SMRC, 2011.

[45] M. J. Aguado, and J. Dato, "InfoVía Plus y la nueva generación de servicios IP, ” Comunicaciones de Telefónica I+D, 17, pp. 5-18, 1999., pp. 5-18.

[46] M. Congosto, "MORE: un avance hacia la digitalización," Madrid: FHT, 2018.

[47] M. Castells, Nuevas tecnologías, economía y sociedad en España, 1, Madrid: Alianza, 1986

[48] Telefónica Móviles España, Informe anual 2005, pp. 56-58.

[49] OECD Communications Outlook 2009, Paris: OECD, 2009, p. 93.

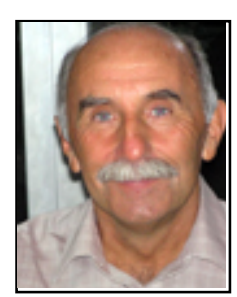

Ángel Calvo, Muro (Soria, Spain), 1949.

Ángel Calvo holds a $\mathrm{PhD}$ in History and he is Emeritus at the University of Barcelona, Spain. $\mathrm{He}$ has published numerous, and articles in both Spanish and international journals of recognised prestige. His lines of research focus on telecommunications, technology transfer as well as industrial and business history. It also highlights his work as dissertations director, membership of the editorial board of several journals in his field, papers reviewer for national and international journals and media advisor. Dr. Calvo has been a member of the Board of Directors of the Societat Catalana d' Història de la Ciència i de la Tècnica since its foundation and belongs to several international groups and associations, such as that tied to the European Science Foundation, the Eurasia Business and Economics Society and the Spanish Society of Economic History. His recent publications include the following: History of Telefonica: 1976-2000. Telecommunications in Democratic Spain, Ariel-Fundación Telefonica, Barcelona, 2016; Telecommunications and the new digital world in Spain: the contribution of Standard Eléctrica, Ariel-Fundación Telefonica, Barcelona, 2014; History of Telefónica: 1924-1975. First decades: technology, economy and politics, Ariel-Fundación Telefonica, Barcelona, 2010; "The emergence of global companies in the high-tech industry of defense: the case of Indra in Spain, 1993-2007," Eurasian Journal of Social Sciences, 7(1), 2019, pp. 29-47. 